\title{
A review of global trends in CITES live wildlife confiscations
}

\author{
Neil D’Cruze ${ }^{1,2}$, David W. Macdonald' \\ I The Wildlife Conservation Research Unit, Department of Zoology, University of Oxford, The Recanati-Ka- \\ plan Centre, Tubney House, Abingdon Road, Tubney OX13 5QL, UK 2 World Animal Protection, 5th Floor, \\ 222 Grays Inn Road, London WC1X 8HB, UK
}

Corresponding author: Neil D'Cruze (neil.dcruze@zoo.ox.ac.uk)

Academic editor: K. Henle | Received 25 July 2016 | Accepted 9 September 2016 | Published 22 September 2016

http://zoobank.org/36EE2B57-7594-4A4F-9FD5-AED3AC5FEBD7

Citation: D'Cruze N, Macdonald DW (2016) A review of global trends in CITES live wildlife confiscations. Nature Conservation 15: 47-63. doi: 10.3897/natureconservation.15.10005

\begin{abstract}
We assessed the global scope and scale of confiscated live wild vertebrates using information from the annual Convention on International Trade in Endangered Species of Flora and Fauna (CITES) reports. These reports documented a total of 64,143 individual animals (from 359 species), confiscated by 54 countries party to CITES, between 2010 and 2014. Reptiles represented 95\% of individuals seized and posed a particular management challenge during this time. From a conservation perspective, 19\% of all individuals reported as seized are currently considered as "Threatened" according to the IUCN Red List and 1\% are listed on CITES Appendix I. During this time period, relevant national enforcement agencies have had to effectively detect and quickly deal with illegal live shipments involving a diverse array of vertebrate species with varying psychological attributes, physiological attributes and conservation value. However, we raise pre-existing concerns that CITES records are incomplete, with no data on live seizures provided by $70 \%$ of countries party to CITES. Data on the disposal of confiscated live animals is also lacking as providing them is not currently a formal CITES requirement. This lack of information impedes the proper allocation of available resources and prevents the effective monitoring and evaluation of management outcomes. Therefore, we recommend that the management authorities improve reporting compliance, and we encourage the CITES trade database (and other associate national, regional and global databases) to include information on the disposal of all live seizures.
\end{abstract}

\section{Keywords}

Animal Welfare, Conservation, Enforcement, Illegal Wildlife Trade, Seizures

Copyright N. D'Cruze, D.W. Macdonald. This is an open access article distributed under the terms of the Creative Commons Attribution License (CC BY 4.0), which permits unrestricted use, distribution, and reproduction in any medium, provided the original author and source are credited. 


\section{Introduction}

Poaching of threatened species to supply the illicit global wildlife trade (IWT) is estimated to be worth between $\$ 8$ and $\$ 10$ billion per year (Lawson and Vines 2014). As the global human population increases, and as the economies of developing countries grow rapidly, demand for wildlife and hence the IWT flourishes (Baker et al. 2013; Zhou et al. 2015a). International travel and transport of goods are now commonplace, and they facilitate movement of live wild animals and products derived from them (e.g. ivory, shells and scales) through illegal and irregular (i.e. under the guise of legal) pathways (Dutton et al. 2013; Zhou et al. 2014a). New media platforms are also having a strong influence promoting IWT, with increased online advertisement and access to information further stimulating demand (Bush et al. 2014; Moorhouse et al. 2016).

IWT is a substantial threat to wild populations through biodiversity loss, species loss, the introduction of invasive species, irresponsible wild release of confiscated animals and disease (Bush et al. 2014; Zhou et al. 2014a). IWT also has negative impacts on animal welfare during illegal capture, improper captive breeding, transport, sale and subsequent use (Baker et al. 2013). IWT embraces wider societal issues, such as a zoonotic risk to human health (Macdonald and Laurenson 2006) and disease risk to livestock (Gómez and Aguirre 2008). Increased understanding of the links with other forms of organized criminal activity is also highlighting how IWT could threaten the stability and security of some societies (Lawson and Vines 2014).

In recognition of these threats, improved regulation of wildlife trade and associated enforcement action has led to an increase in the number of illegal and irregular wildlife shipments intercepted by government authorities (CITES 2010). Yet efforts to try and bypass enforcement agencies continue, with criminal actors employing tactics involving both wild caught and captive bred wild animals that include: (1) concealment of contraband live wild animals and their derivatives within shipments; (2) false declaration of numbers within shipments; (3) false declaration of wild-caught specimens as 'captive bred'; and (4) false declaration of the source as "pre-convention" or "seized" (Kasterine et al. 2012; Lyons and Natusch 2011; Williams et al. 2015; Zhou et al. 2014b; Zhou et al. 2015b). With regards to live wild animals, these tactics are used to meet consumer demand for working animals, pets, companionship, entertainment, and status symbols (Baker et al. 2013).

In order to effectively detect, monitor and address IWT, national authorities require detailed centralized information (such as the source, date, location, species, quantity, intended destination and purpose) regarding seized shipments (UNODC 2012). Currently, a small number of countries are reported to maintain national databases that record such information (UNODC 2012). In addition, this type of data is also recorded in a number of regional [e.g. the European Union's Trade in Wildlife Information Exchange (EUTWIX; www.eutwix.org)] and international databases [e.g. The World Customs Organization's (WCO) Customs Enforcement Network (CEN); 
and the World Wildlife Seizure database (World Wise), a developing initiative led by the United Nations Office on Drugs and Crime (UNODC)]. However, of the existing IWT databases, only seizure information from the Convention on International Trade in Endangered Species of Flora and Fauna (CITES) trade database is currently made fully available to the public for subsequent interpretation and analysis.

CITES is an international agreement that operates as a licensing system through which imports and exports of listed species must be authorized by Parties (UNEPWCMC 2014). There are currently 182 Parties to CITES, who are under obligation to enact this international framework within their own national legislative system (CITES 2014) with varying degrees of effectiveness (D'Cruze and Macdonald 2015). Countries that are party to CITES are required to submit annual reports of international trade, including seizures of listed species, which are made available on the United Nations Environment Program World Conservation Monitoring Centre (UNEP-WCMC) CITES trade database (http://trade.cites.org/). Poor reporting compliance, for example non-standardized, insufficient and absent data have been identified as an on-going issue of concern associated with the CITES trade database (UNEP CITES 2014). However, these data have still proved revealing in previous studies of trade in wild animals (e.g. Bush et al. 2014; Harrington 2015; D’Cruze and Macdonald 2015).

Herein, we review the annual CITES reports between 2010-2014 to examine the current extent of live wild vertebrate trade seizures with respect to the five classes of vertebrates principally involved (amphibians, birds, fish, mammals and reptiles). Specifically, we asked: (1) what taxonomic groups are being seized most frequently; (2) how many individual animals are involved; (3) what are their conservation and legislative status; and (4) where are these seizures most frequently taking place. We intend the information gathered to guide existing efforts to both conserve remaining wild populations and to safeguard the welfare of individual confiscated wild animals.

\section{Methods}

We queried the CITES trade database for all live wild animal seizures for the years 2010-2014 inclusive. Trade data on CITES live animal seizures were supplied in the form of a Comparative Tabulation Table (data collated 01 Jan 2016 - see UNEPWCMC (2014) for detailed explanation on data) (Suppl. material 1). This output was chosen deliberately because in addition to export and import data, it also provides information on the source and purpose of wildlife trade transactions (UNEP-WCMC 2014). Information regarding the conservation status and the regional distribution of wild populations for the species involved in wildlife seizures was gathered from the IUCN Red List of Threatened species (IUCN 2016).

We specifically requested data only using the "live" trade term and the CITES source code "I" which refers to illegal trade seizure records as outlined in Notifica- 
tion 2002/022 (UNEP-WCMC 2014). We focussed our analyses on the following five taxonomic classes of vertebrate provided in the database: Actinopterygii ('bony' fish), Aves (birds), Amphibia (amphibians), Mammalia (mammals) and Reptilia (reptiles). We chose to exclude records of wildlife derivatives from our study as a lack of information on volumes seized is already known to hinder such analyses (UNEP-WCMC 2014; D'Cruze and Macdonald 2015). Seizure data were available in the CITES trade database from 54 different countries, with $30 \%$ of the countries party to CITES, in Asia $(n=10 ; 6 \%)$, Africa $(n=5 ; 3 \%)$; Australasia $(n=2 ; 1 \%)$, Europe $(n=25 ; 14 \%)$, North America $(n=2 ; 1 \%)$, and South America $(n=6 ; 3 \%)$ (Suppl. material 1$)$.

All purpose codes outlined in Notification 2002/022 that are available to CITES Parties were used in the analysis including: captive breeding (CITES purpose code B), circus $(\mathrm{Q})$, commercial $(\mathrm{T})$, educational $(\mathrm{E})$, personal $(\mathrm{P})$, scientific $(\mathrm{S})$, and zoo (Z) use (UNEP-WCMC 2014). All Appendix classifications used by CITES were also included in the analysis: Appendix I (trade permitted only under exceptional circumstances), Appendix II (non-detriment finding and export permit are required for trade), Appendix III (one Party has asked other CITES Parties for assistance in controlling trade), or non-CITES (CITES 1973).

Following the completion of this review we described tabulated categorical data using descriptive statistics, including percentages, pie charts and bar charts. We used a contingency table to test the hypothesis that the proportions of endangerment classes were similar among taxonomic groups. We used general linear models with mean separation tests using SPSS statistical software (version 22.0, IBM SPSS Statistics, New York, USA) to test for trends in numbers with year and for differences between taxa. We also tested the hypothesis that temporal trends among taxa were similar by including the interaction term between year and group. For all analyses we used the declared state of origin over exporting country if data were available and were different.

\section{Results}

During the period 2010-2014, a total of 785 live vertebrate seizure records, comprised of both illegal and irregular shipments, were officially received by CITES according to the comparative tabulation report (Suppl. material 1). These seizures involved 64,143 individual animals belonging to 359 different species. A total of 24 records could not be identified down to species level and were recorded as "spp." (e.g. Falconidae spp.). However, the remaining 335 species were all identified to species level in the CITES reports (Suppl. material 1). Information regarding the regional distribution of wild populations was available for 292 of the species officially reported as seizures in the CITES trade database (IUCN 2016). A total of 100 (34\%) of these 292 species are known to have extant wild populations in Asia; 95 species (33\%) are present in Africa; 94 species (32\%) are present in South America; 75 species (26\%) are present in North America; 43 species (15\%) are present in Australasia; and 31 species (11\%) are present in Europe (Suppl. material 1). 


\section{Most targeted taxa}

According to CITES trade database, reptiles were the most species-rich taxonomic class reported as live seizures, followed by birds, mammals, fish and amphibians (Fig. 1). Psittaciformes (parrots etc.) were the most species-rich taxonomic order recorded as live seizures, followed by Sauria (lizards etc.), Testudines (turtles etc.), Serpentes (snakes etc.), Primata, Carnivora, and Falconiformes (falcons etc.) (Fig. 1). With regards to the number of individual live animals, reptiles were the class most commonly reported as live seizures, followed by fish, birds, mammals and amphibians (Fig. 2).

Within reptiles, the False Map Turtle [Graptemys pseudogeographica (23,201 individuals; 8 separate seizures)] was the species most commonly reported among live seizures (Fig. 3; Suppl. material 1). The Ball Python [Python regius (12,172 individuals; 23 separate sei-
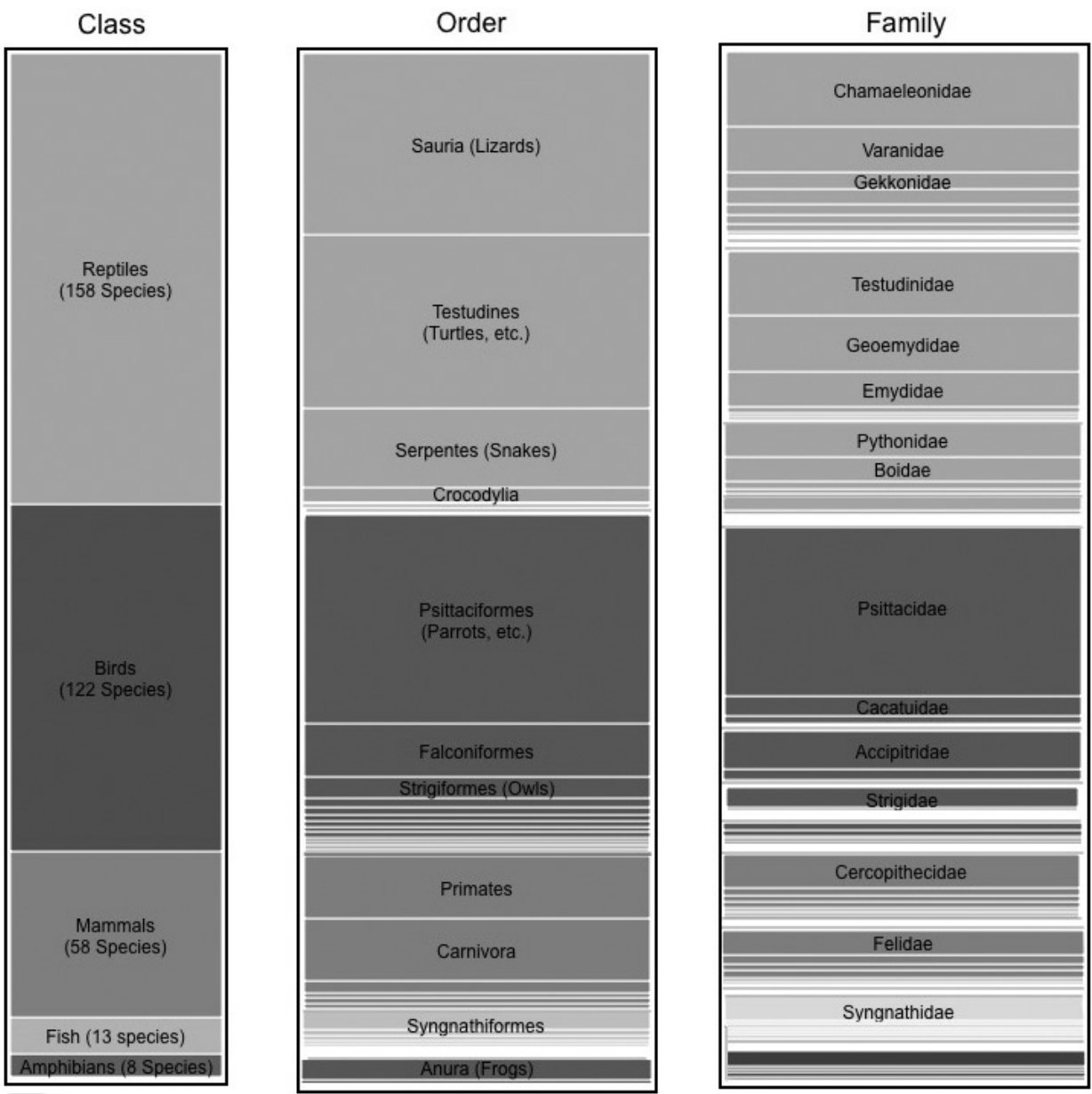

Figure I. Proportion of species reported as live vertebrate seizures, according to different taxonomic groups, between 2010-2014. Data source: CITES trade database. 


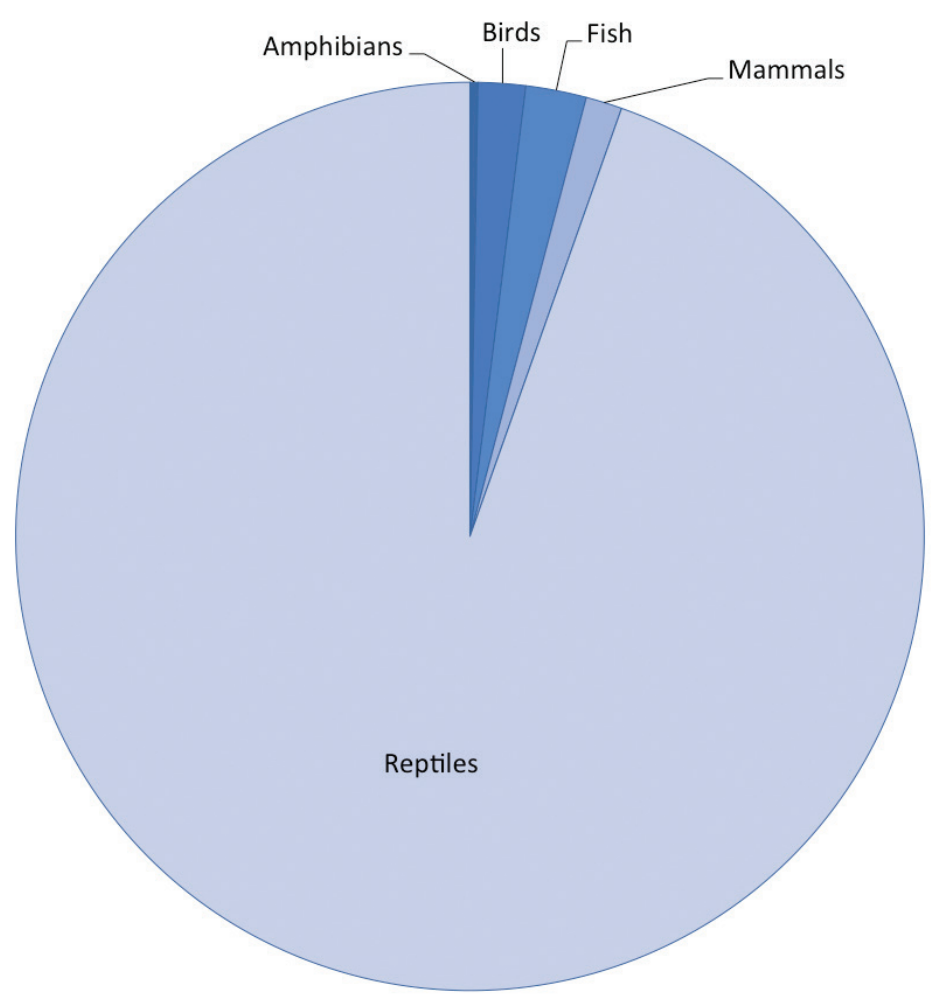

Figure 2. Total numbers and proportions of individual live wild vertebrates seized, according to taxonomic group, between 2010-2014. Data Source: CITES trade database.

zures)] was the second most commonly reported species followed by the Russian Tortoise [Testudo horsfieldii (7,115 individuals; 7 separate seizures)], an unknown Map Turtle hybrid [Graptemys spp. (4,500 individuals; 2 separate seizures)] and the Ouachita Map Turtle [Graptemys ouachitensis (2,630 individuals; 3 separate seizures)] (Fig. 3; Suppl. material 1).

The only non-reptile species among the ten most commonly reported species was the Crab-Eating Macaque [Macaca fasicularis (482 individuals; three seizure records)] (Fig. 3; Suppl. material 1). The Common Seahorse [Hippocampus kuda (465 individuals; 5 seizure records)] the Long-Snout Seahorse [Hippocampus reidi (267 individuals; 7 seizure records)] and the European Eel [Anguilla anguilla (235 individuals; 1 seizure record)] were the only other non-reptile species among the 20 most commonly reported species according to CITES records (Suppl. material 1).

\section{Taxonomic trends}

A peak of 21,425 animals was seized in 2011 and the lowest number of live animals seized $(n=6,049)$ was reported from 2014 (Suppl. material 1$)$. There was no evidence 


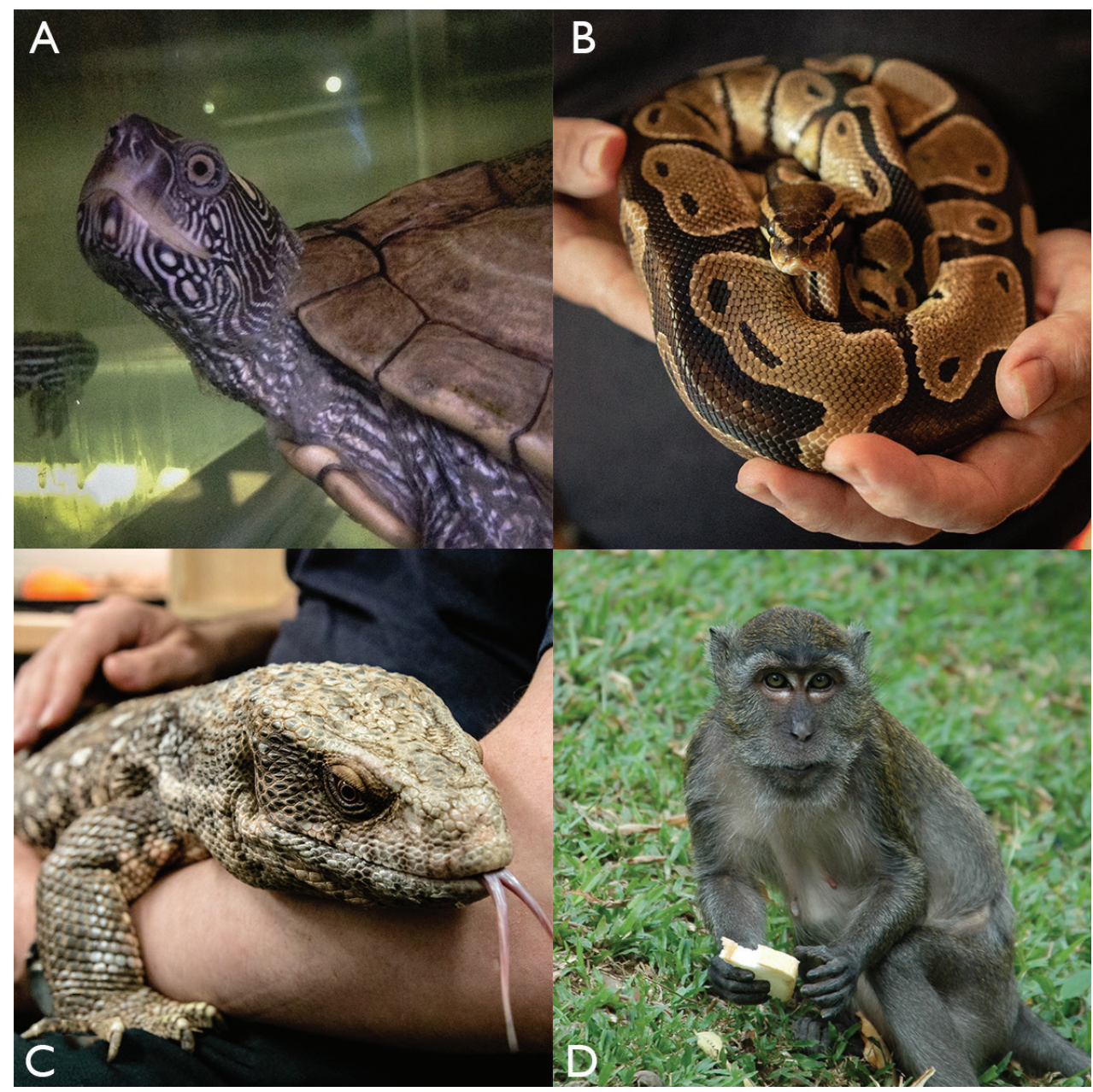

Figure 3. Species commonly reported as live wild vertebrate seizures by CITES between 2010-2014. A False Map Turtle (23,201 individuals seized) B Ball Python (12,172 individuals seized) C Bosc's Monitor (1,705 individuals seized) D Crab-Eating Macaque (482 individuals seized). Photo credit A Maxine Bradley B, C Neil D’Cruze D Jan Schmidt-Burbach (credited permission to use these images has been provided by owners).

for an overall trend in numbers of live individuals seized with year $\left(\mathrm{F}_{1,15}=0.24, \mathrm{P}=>\right.$ $0.05)$ or that this differed among taxonomic groups $\left(\mathrm{F}_{4,15}=0.16, \mathrm{P}=0.96\right)$. There was strong evidence that the number of live individuals seized differed among taxonomic groups $(\mathrm{F}=28.22, \mathrm{P}<0.001)$ - reptiles are more numerous than the other groups (Tukey means separation procedure).

With regards to trade purpose, the vast majority of seized live animals ( $n=60,850$; 95\%) were intended for commercial use according to CITES records (Suppl. material 1). Law enforcement (e.g. judicial and or forensic) use ( $n=1072 ; 2 \%)$ was the second most common intended trade purpose reported, followed by breeding in captivity $(n$ 
$=354 ; 1 \%)$, personal use $(n=338 ; 1 \%)$, zoological use $(n=185 ;<1 \%)$, medical use $(n=137 ;<1 \%)$, reintroduction into the wild $(n=111 ;<1 \%)$, scientific use $(n=30$; $<1 \%)$, educational use $(n=13 ;<1 \%)$ and circus use $(n=6 ;<1 \%)$ (Suppl. material 1$)$. No purpose data were provided for 1,056 (2\%) of the live individual animals seized, recorded by CITES during the period 2010-2014 (Suppl. material 1).

\section{Conservation and legislative status}

In terms of conservation status, there was strong evidence that the proportions of different IUCN Red List categories differed among taxa $\left(X^{2}=23,304, P<0.001, D F=\right.$ $36)$. Overall the majority of individual animals seized belong to species currently considered as "Least Concern" on the IUCN Red List of Threatened species $(n=44,371$; 69\%) (Fig. 4). In total, 11,902 of all individuals seized (19\%) are currently considered to have "Threatened" status according to the IUCN Red List (i.e. they are listed as either "Critically Endangered", "Endangered" or "Vulnerable" (Fig. 4).

With regards to their CITES status, overall the largest proportion of individuals belong to species that are currently listed on CITES Appendix III $(n=30,602 ; 48 \%$ of all individuals recorded in seizures) (Fig. 5). A further 29,202 (46\%) of individuals belong to species currently listed on CITES Appendix II. A total of $852(1 \%)$ are currently listed on CITES Appendix I, and a further 10 individuals $(<1 \%)$ are not currently listed on any of the CITES Appendices (Fig. 5).

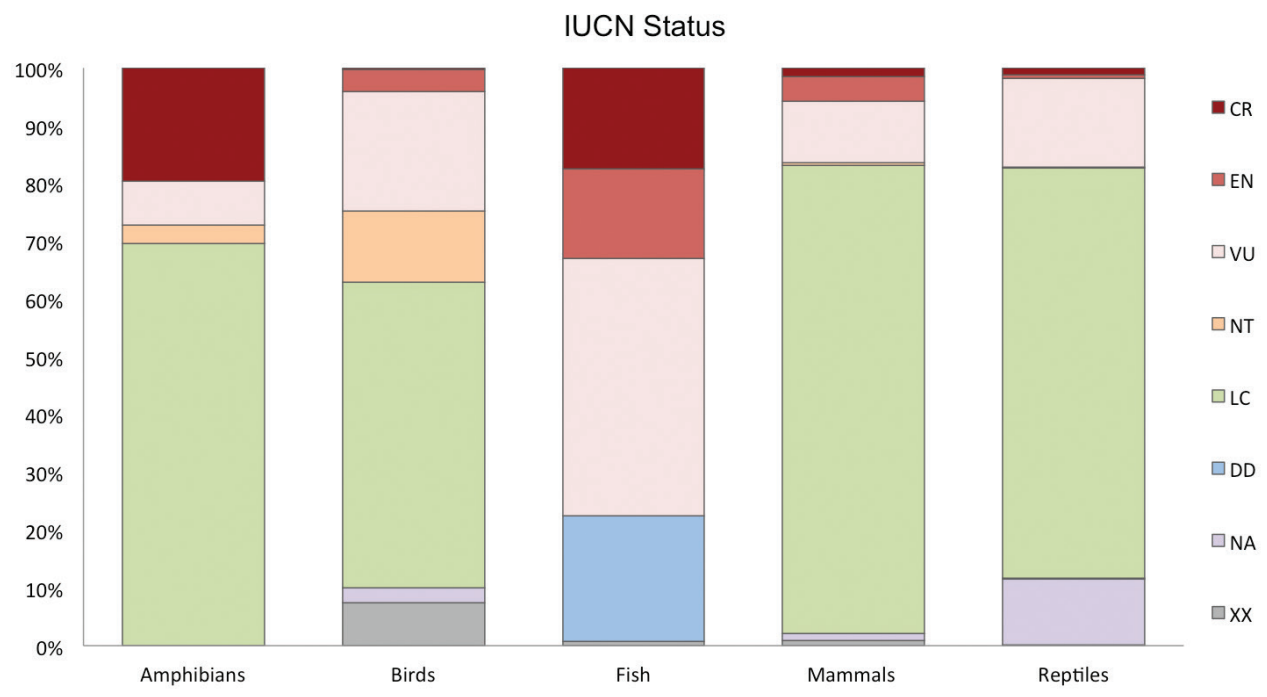

Figure 4. Proportion of individuals reported as live wild vertebrate seizures, according to IUCN Red List status, between 2010-2014. (IUCN Red List assessment categories: CR, critically endangered; EN, endangered; VU, vulnerable; NT, near threatened; LC, least concern; DD, data deficient; NA, not yet assessed; XX, not listed). Data source: CITES trade database. 


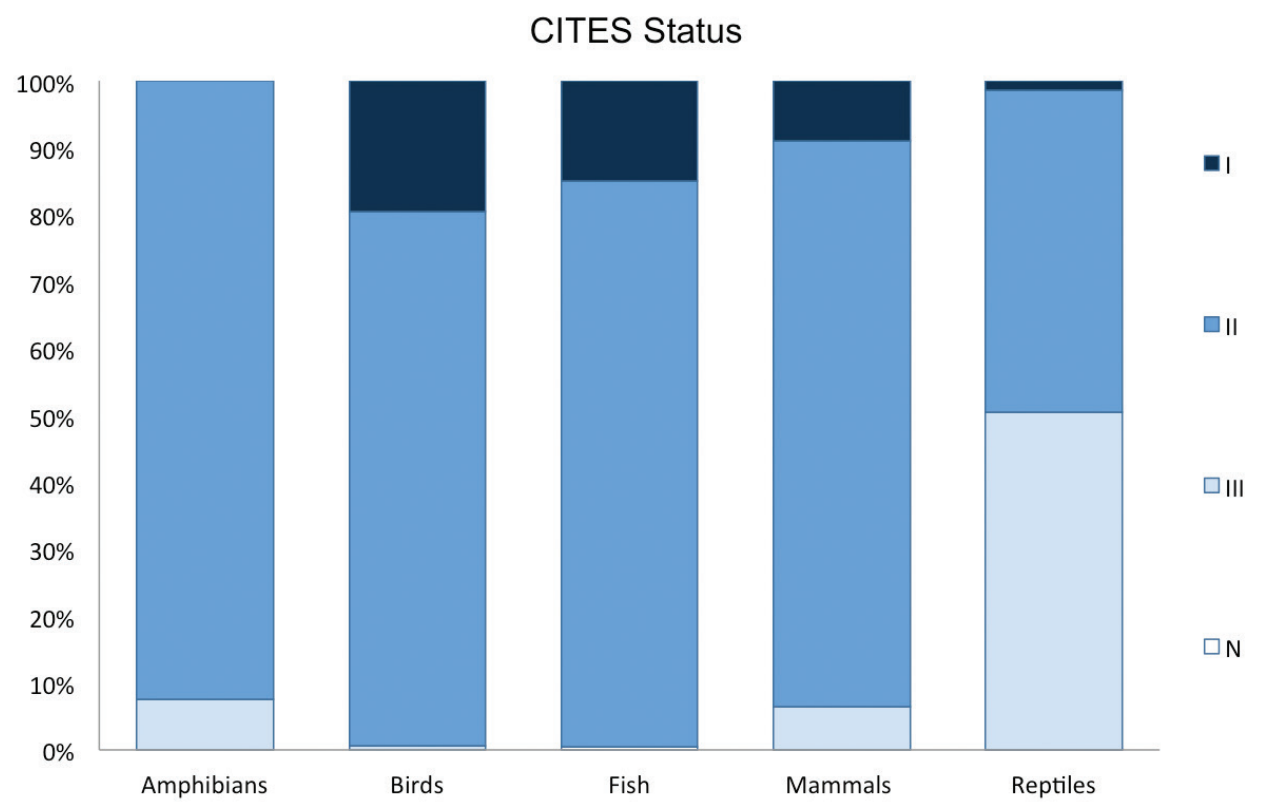

Figure 5. Proportion of individuals reported as live wild vertebrate seizures, according to CITES status, between 2010-2014. (CITES appendix listings: I, CITES Appendix I; II, CITES Appendix II; III, CITES Appendix III; N, not listed). Data source: CITES trade database.

\section{Site of seizure}

In total, 36,746 individual live animals were seized by relevant national enforcement authorities upon export and a further 27,397 individuals were seized during import (Suppl. material 1). The number of live wild vertebrates seized during import [amphibians ( $n=146$ individuals), birds $(n=678)$, fish $(n=1,374)$ and mammals $(n=710)]$ was higher than those seized upon export for all taxonomic groups except reptiles. In contrast, 27,397 individual reptiles were seized upon import whereas 36,177 individual reptiles were seized upon export. With regards to the 11,902 seized live wild animals that are currently considered as Threatened according the IUCN Red List, in total 7,036 individuals (59\%) were seized upon import [amphibians $(n=23$ individuals), birds $(n=117)$, fish $(n=1,073)$, mammals $(n=$ $75)$ and reptiles $(n=5,748)$.

Seizure data regarding live wild vertebrates confiscated between 2010-2014 were available in the CITES trade database from 54 different countries which represent $30 \%$ of all countries party to CITES. The majority of individuals were seized in the USA (90\%), followed by Uzbekistan (5\%), Malaysia (1\%), Portugal (1\%) and the United Arab Emirates $(<1 \%)$. A total of 2,072 animals were reported as seized by all of the remaining 49 countries combined (Fig. 6). 


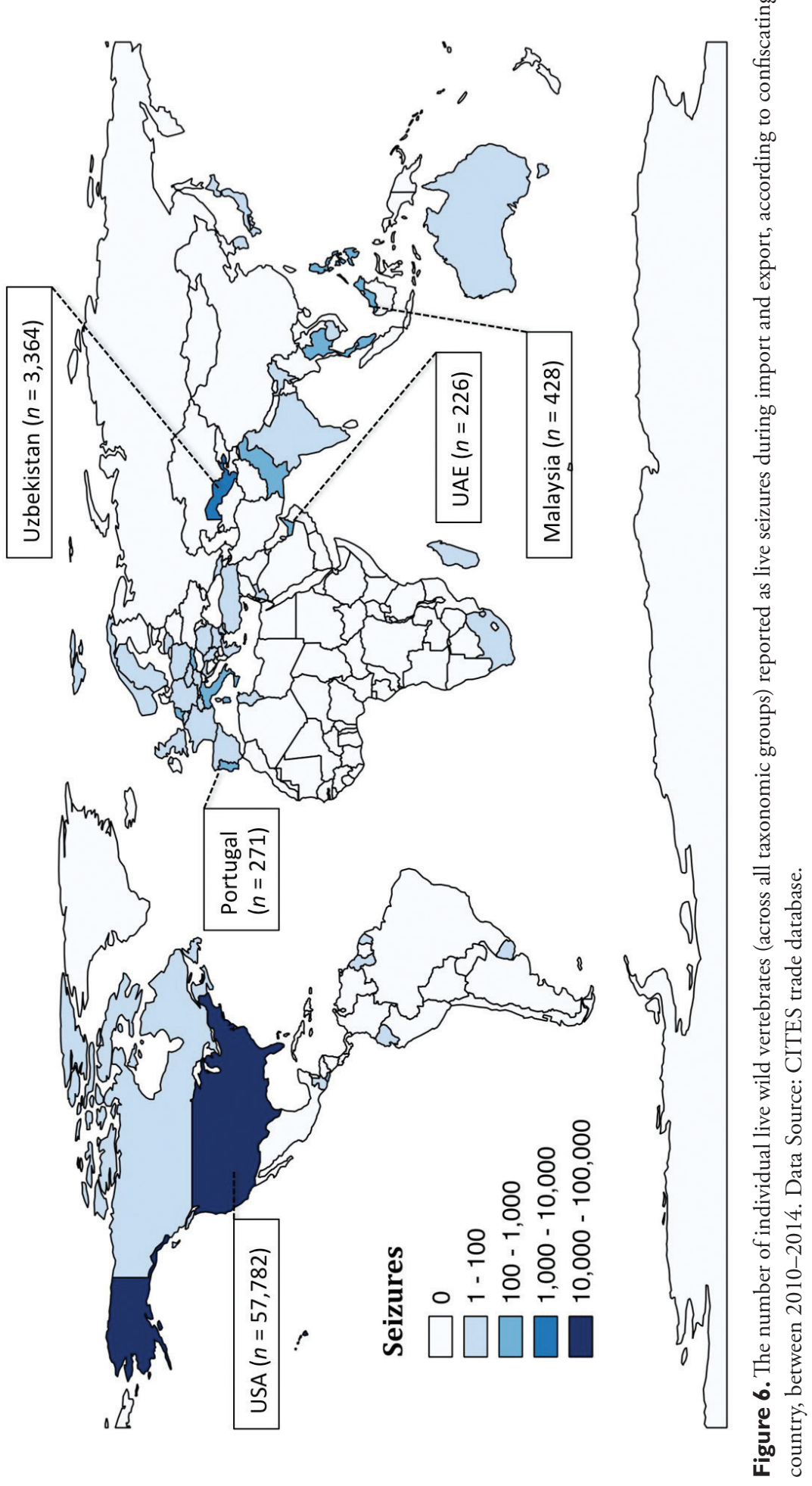




\section{Discussion}

We reviewed the annual CITES reports to assess the scope and scale of live wild vertebrate trade seizures made between 2010-2014. Overall, our findings are comparable to other studies, for example Rosen and Smith (2010) reported that 191,936 live wild animals were seized between 1996 and 2008 according to TRAFFIC records. Similarly, our study demonstrates that over the past five years, relevant national enforcement agencies in more than 50 different countries have had to effectively detect and quickly deal with illegal and irregular live shipments involving at least 60,143 live individual animals from 359 different wild vertebrate species with varying psychological attributes, physiological attributes and conservation value (e.g. Nijman et al. 2010; TRAFFIC 2008; TRAFFIC 2013).

Following each of these seizures, the relevant CITES Management authorities were expected to have dealt with these confiscated live wild vertebrates in a humane manner that maximized their conservation value and that did not promote further unsustainable illegal wildlife trade (CITES 2010; IUCN 2013). Allowable options available to them fall into three principal categories: (1) maintenance of the individuals in captivity; (2) returning the individuals in question to some form of life in the wild; and (3) euthanasia (CITES 2010; IUCN 2013), dependent on other legal, economic and social factors such as cultural attitudes (Chris Newman pers. comms.). The impact of their decisions in this regard would have important ramifications for both animal welfare and the conservation of wild populations.

\section{Conservation Implications}

Overall, the largest proportion of live wild vertebrates seized between 2010-2014 involved species that are currently considered to be of relatively low risk of extinction. Specifically, 69\% of all individuals reported are currently considered as "Least Concern" according to the IUCN Red List and 48\% are listed on CITES Appendix III. As such, the majority of individuals seized during this time do not appear to be of immediate conservation concern. However, it is important to note that IWT is recognised to be a big and burgeoning business (Baker et al. 2013). Given that it has also been identified as one of the main challenges to conservation (Lawson and Vines 2014), special attention should be paid to ensure that on-going unregulated illegal trade in these species does not become a threat to species survival in the future.

A far smaller proportion of live wild vertebrates seized between 2010-2014 involved species that are currently considered to be of relatively high risk of extinction. Specifically, only 19\% of all individuals reported as seized are currently considered as "Threatened" according to the IUCN Red List and only 1\% are listed on CITES Appendix I. However, despite the relatively small number of individuals involved, the impact of this IWT on remaining wild populations and the conservation value of these "Threatened" wild animals should not be underestimated. For example, the poaching 
of even a small number of "Critically Endangered" individuals could prove catastrophic for remaining wild populations. Similarly, the incorporation of these confiscated live animals into official wild release programmes could help to safe guard their future survival if managed properly (CITES 2010; IUCN 2013).

It should be noted that agency efforts to return confiscated live animals of high conservation status back into the wild may have been hampered by the fact that $59 \%$ of "Threatened" individuals seized (2010-2014) took place during import rather than upon export (Suppl. material 1). From a technical perspective this can make wild release more challenging as data regarding the country of origin and or site of capture may be lacking (D'Cruze and Macdonald 2015). From a financial perspective, live animals confiscated on import are also more expensive to release due to the extra costs associated with their repatriation (Beck at al. 2007). This may be of particular concern for countries lacking available financial resources as importing countries are currently expected to bear the economic costs of disposal (CITES 2010).

\section{Animal Welfare Implications}

From an animal welfare perspective, each of the 64,143 individual live wild animals seized between 2010-2014 will have posed a management issue for the agencies involved. In terms of sheer numbers, it appears that illegally traded reptiles (95\% of all live wild vertebrates reported as seized) were a particular challenge during this time period. However, it is important to note that even the species seized in far fewer numbers (e.g. primates) could have proved equally, if not more problematic during confiscation and disposal in this regard (e.g. Farmer 2002; Campbell et al. 2015). In particular, the large proportion of individuals seized during import (43\%) are of considerable animal welfare concern as (in addition to suffering experienced during capture and preparation) these animals will have also had their physical and mental states further compromised during illegal shipment after export (Warwick 2014).

Historically, decisions on the disposal of confiscated live animals have been influenced by the perception that returning them to the wild is the optimal solution for animal welfare and conservation (CITES 2010). Although this may be the preferred option, for species of high conservation status and often the welfare of individual animals, a growing body of scientific evidence suggests that such action is not always the most appropriate decision (IUCN 2013). For example, the poorly planned release of confiscated animals into the wild may doom them to a slow, painful death (CITES 2010) and may also threaten the welfare and survival of wild populations by exposing them to disease and genetic pollution (IUCN 2013). Given these risks, and recommendations provided in current guidelines (CITES 2010; IUCN 2013), it is likely that the provision of life time care and euthanasia would have been the preferred options for the majority of wild animals seized between 2010-2014 due to their relatively low conservation status. 


\section{Limitations of the CITES Seizure Data}

Using seizure records to assess the actual amount of IWT and associated enforcement effort taking place over a given time period is hindered by the fact that not all illegal transactions are seized and not all seizures are recorded officially (Underwood et al. 2013). This is because efforts to control and report on IW'T can vary between countries depending on a variety of factors including political will, available resources, levels of corruption (UNODC 2016), the species involved [for example due to difficulties in identifying prohibited taxa (e.g. Zhou et al. 2015c)] and due to real or perceived technical challenges in dealing with confiscated individuals (Underwood et al. 2013).

In particular, poor reporting compliance has already been identified as an on-going issue of concern associated with the CITES trade database (UNEP CITES 2014; D'Cruze and Macdonald 2015). In light of this fact, and also taking the other various factors outlined above into account, it is unlikely that no international illegal trade activity took place in the $128(70 \%)$ countries party to CITES for which no seizure events were reported (Suppl. material 1). Therefore, applying the precautionary principle, it is not unreasonable to treat the total of 64,143 confiscated live wild vertebrates (including the 11,902 live individuals of threatened status) reported in the CITES trade database as a highly conservative figure.

Another specific issue of concern is the fact that CITES does not require Parties to formally record any information regarding the disposal of confiscated live wild animals. This lack of information impedes the monitoring, evaluation and improvement of any disposal decisions taken which could be jeopardizing both animal welfare and the survival of remaining wild populations. As a case in point, currently it is not possible to establish how many seized wild animals have re-entered commercial trade even though this option is only recommended in certain circumstances where "there are no concerns that sale will stimulate further illegal or irregular trade" and "qualified buyers exist" (CITES 2010).

\section{Future recommendations}

Our study raises pre-existing concerns that information regarding the actual number of live wild vertebrates seized by CITES Management authorities each year is incomplete. Furthermore, where seizure records do exist, information regarding the ultimate fate of these wild animals is not currently documented in the CITES trade database. To address this issue, we recommended that the relevant Management authorities improve reporting compliance and that CITES strengthens its trade database in continued collaboration other associated national, regional and global data management platforms (UNODC 2016) to include data on the disposal of any live wild animal seizures that are officially recorded (Table 1 ).

Enforcement agencies must also have the financial resources needed to effectively seize live IWT (Moore et al. 2015), preferably prior to international export. A range 
Table I. Key challenges and management recommendations for the effective seizure and disposal of live animals seized by CITES authorities.

\begin{tabular}{lll}
\hline \multicolumn{1}{c}{ Concern } & \multicolumn{1}{c}{ Continuing Challenge } & \multicolumn{1}{c}{ Recommendation } \\
\hline \multirow{4}{*}{$\begin{array}{l}\text { Legislative and regu- } \\
\text { latory measures }\end{array}$} & $\begin{array}{l}\text { Non-existent national action plans for } \\
\text { effective seizure and disposal of live }\end{array}$ & $\begin{array}{l}\text { Each Party develops a plan of action to be } \\
\text { executed following live CITES seizures }\end{array}$ \\
\cline { 2 - 3 } & $\begin{array}{l}\text { CITES seizures } \\
\text { Incomplete understanding of which na- } \\
\text { tional agencies are responsible for effective } \\
\text { seizure and disposal of live CITES seizures }\end{array}$ & $\begin{array}{l}\text { Each Party identifies (in CITES direc- } \\
\text { tory) national agencies with authority to } \\
\text { act on disposal of live CITES seizures }\end{array}$ \\
\hline \multirow{3}{*}{$\begin{array}{l}\text { National and inter- } \\
\text { national law enforce- } \\
\text { ment }\end{array}$} & $\begin{array}{l}\text { National enforcement agencies lack the } \\
\text { financial resources for effective seizure } \\
\text { and disposal of live CITES seizures }\end{array}$ & $\begin{array}{l}\text { Criminal actors bear the financial costs } \\
\text { for disposal of live animal CITES seizures }\end{array}$ \\
\cline { 2 - 4 } $\begin{array}{l}\text { National enforcement agencies lack the } \\
\text { skilled staff for effective seizure and dis- } \\
\text { posal of live CITES seizures }\end{array}$ & $\begin{array}{l}\text { Each Party provides formal training for } \\
\text { staff involved in the seizure and disposal } \\
\text { of live CITES seizures }\end{array}$ \\
\hline \multirow{2}{*}{$\begin{array}{l}\text { Trade data recording } \\
\text { and analysis }\end{array}$} & $\begin{array}{l}\text { Incomplete national CITES WCMC } \\
\text { trade database live seizure records }\end{array}$ & $\begin{array}{l}\text { Strengthen existing CITES WCMC in- } \\
\text { ternational data management platforms }\end{array}$ \\
\cline { 2 - 4 } & $\begin{array}{l}\text { Non-existent national live disposal re- } \\
\text { cords in CITES WCMC trade database }\end{array}$ & $\begin{array}{l}\text { Strengthen CITES WCMC data man- } \\
\text { agement platform to include data on } \\
\text { disposal of live CITES seizures }\end{array}$ \\
\hline \multirow{3}{*}{$\begin{array}{l}\text { Consumer demand } \\
\text { reduction }\end{array}$} & $\begin{array}{l}\text { Growing international demand for il- } \\
\text { legally traded live wild animals }\end{array}$ & $\begin{array}{l}\text { Initiate new international behaviour } \\
\text { change focused interventions }\end{array}$ \\
\cline { 2 - 4 } & $\begin{array}{l}\text { Sustained domestic demand for illegally } \\
\text { traded live wild animals }\end{array}$ & $\begin{array}{l}\text { Strengthen existing national behaviour } \\
\text { change focused interventions }\end{array}$ \\
\hline
\end{tabular}

of potential funding sources is available to cover these costs (e.g. private donations and government allocations) (CITES 2010). However, given its potential to act as a disincentive for IWT, we specifically recommended that countries adopt new and/or strengthen existing legislation in order to charge the criminal actors with the costs associated with the seizure and disposal of confiscated live wild animals (CITES 2010) (Table 1). A formal CITES wildlife policy review could prove useful by identifying specific actions to address any discrepancy between formal compliance (i.e. what is actually required) and real compliance (i.e. what is currently being provided) (CITES 2016).

\section{Conclusion}

The two primary legal instruments used to address unsustainable exploitation of wildlife are out-right bans [e.g. the European Union "blanket" ban on the import of captive live birds (BBC 2005)] and conditional allowances permitting limited trade [e.g. (international trade in CITES listed species)] (Dutton et al. 2013). Although both expert and public opinion is often polarised regarding which of these instruments will be most effective for a given wildlife trade issue, the general consensus is that increas- 
ing IWT involving live animals sourced both from the wild (e.g. D'Cruze et al. 2015) and captivity (e.g. Nijman and Shepherd 2015) will remain an on-going issue of global animal welfare and conservation concern (e.g. UNODC 2016). Although it will never be possible to detect and seize all live IWT, we call for improved data reporting and enforcement activity, in combination with existing recommendations to increase political will and reduce consumer demand (TRAFFIC 2008; CITES 2010) (Table 1).

\section{Acknowledgements}

We gratefully acknowledge the input of Margaret Balaskas, Gemma Carder, Paul Johnson, Mark Jones, Staci McLennan, Chris Newman, Kate Nustedt, and Jessica Wood in the preparation of this manuscript. We would like to thank World Animal Protection for providing funding for this study.

\section{References}

Baker SE, Cain R, Van Kesteren F, Zommers ZA, D’Cruze N, Macdonald DW (2013) Rough trade: animal welfare in the global wildlife trade. BioScience 63: 928-938. doi: 10.1525/ bio.2013.63.12.6

BBC (2016) EU bans imports of exotic birds. http://news.bbc.co.uk/1/hi/world/europe/4373584.stm

Beck B, Walkup K, Rodrigues M, Unwin S, Travis D, Stoinski T (2007) Best practice guidelines for the re-introduction of great apes. Species Survival Commission Primate Specialist Group of the World Conservation Union, 48 pp. doi: 10.2305/iucn.ch.2007.ssc-op.35.en

Bush ER, Baker SE, Macdonald DW (2014) Global trade in exotic pets 2006-2012. Conservation Biology 28: 663-676. doi: 10.1111/cobi.12240

Campbell CO, Cheyne SM, Rawson BM (2015) Best practice guidelines for the rehabilitation and translocation of gibbons. IUCN, 56 pp. doi: 10.2305/iucn.ch.2015.ssc-op.51.en

CITES (1973) Text of the Convention. https://www.cites.org/sites/default/files/eng/disc/ CITES-Convention-EN.pdf

CITES (2010) Disposal of confiscated live specimens of species included in the Appendices. Resolution Conf. 10.7 (Rev. CoP15), Doha (Qatar), March 2010, 1-25.

CITES (2016) Wildlife trade policy reviews. https://cites.org/eng/prog/policy/index.php

D'Cruze N, Macdonald DW (2015) Clouded in mystery: the global trade in clouded leopards. Biodiversity and Conservation 24: 3505-3526. doi: 10.1007/s10531-015-1010-9

D'Cruze N, Singh B, Morrison T, Schmidt-Burbach J, Macdonald DW, Mookerjee A (2015) A star attraction: the illegal trade in Indian star tortoises. Nature Conservation 13: 13-1. doi: $10.3897 /$ natureconservation.13.5625

Dutton AJ, Gratwicke B, Hepburn C, Herrera EA, Wunder S (2013) Tackling unsustainable wildlife trade. In: Macdonald DW, Willis KJ (Eds) Key topics in conservation biology. Wiley-Blackwell, Oxford, 74-92. doi: 10.1002/9781118520178.ch5 
Farmer KH (2002) Pan African sanctuary alliance: status and range of activities for great ape conservation. American Journal of Primatology 58: 117-132. doi: 10.1002/ajp. 10054

Harrington LA (2015) International commercial trade in live carnivores and primates 20062012: response to Bush et al. 2014. Conservation Biology 29: 293-296. doi: 10.1111/ cobi. 12448

Gómez A, Aguirre AA (2008) Infectious diseases and the IWT. Annals of the New York Academy of Sciences 1149: 16-19. doi: 10.1196/annals.1428.046

IUCN/SSC (2013) Guidelines for reintroductions and other conservation translocations, $34 \mathrm{pp}$.

Kasterine A, Arbeid R, Caillabet O, Natusch D (2012) The trade in South-East Asian python skins. International Trade Centre (ITC), 1-55.

Lawson K, Vines A (2014) Global impact of the IWT - the costs of crime, insecurity and institutional erosion. Chatham House, 62 pp.

Lyons JA, Natusch DJD (2011) Wildlife laundering through breeding farms: illegal harvest, population declines and a means of regulating the trade of green pythons (Morelia viridis) from Indonesia. Biological Conservation 144: 3073-3081. doi: 10.1016/j.biocon.2011.10.002

Macdonald DW, Laurenson M (2006) Infectious disease: inextricable linkages between human and ecosystem health. Biological Conservation 131: 143-150. doi: 10.1016/j.biocon.2006.05.007

Moore RS, Cabana F, Nekaris KAI (2015) Factors influencing stereotypic behaviours of animals rescued from Asian animal markets: a slow loris case study. Applied Animal Behaviour Science 166: 131-136. doi: 10.1016/j.applanim.2015.02.014

Moorhouse TP, Balaskas MB, D'Cruze N, Macdonald DW (2016) Information could reduce consumer demand for exotic pets. Conservation Letters. doi: 10.1111/conl.12270

Nijman V, Martinez CFY, Shepherd CR (2010) Saved from trade: donated and confiscated gibbons in zoos and rescue centres in Indonesia. Endangered Species Research 9: 151-157. doi: $10.3354 /$ esr00218

Nijman V, Shepherd CR (2015) Adding up the numbers: An investigation into commercial breeding of Tokay geckos in Indonesia. TRAFFIC, 1-9.

Rosen GE, Smith KF (2010) Summarizing the evidence on the international trade in illegal wildlife. EcoHealth 7: 24-32. doi: 10.1007/s10393-010-0317-y

TRAFFIC (2008) What's driving the wildlife trade? A review of expert opinion on economic and social drivers of the wildlife trade and trade control efforts in Cambodia, Indonesia, Lao PDR and Vietnam. East Asia and Pacific region sustainable development discussion papers. The World Bank, 103 pp.

TRAFFIC (2013) Bulletin seizures and prosecutions March 1997-October. TRAFFIC, 1-274.

UNEP-WCMC (2014) A guide to using the CITES Trade Database, version 8. United Nations Environment Program, World Conservation Monitoring Centre, 1-21.

UNODC (2012) Wildlife and forest crime analytic toolkit revised edition. United Nations Office of Drugs and Crime, $212 \mathrm{pp}$.

UNODC (2016) World wildlife crime report: trafficking in protected Species. United Nations Office of Drugs and Crime, $101 \mathrm{pp}$. 
Warwick C (2014) The morality of the reptile "pet” trade. Journal of Animal Ethics 4: 74-94. doi: 10.5406/janimalethics.4.1.0074

Williams VL, Newton DJ, Loveridge AJ, Macdonald DW (2015) Bones of contention: an assessment of the South African trade in African lion Panthera leo bones and other body parts. TRAFFIC and Oxford: WildCRU, $128 \mathrm{pp}$.

Zhou Z-M, Zhou Y, Newman C, Macdonald DW (2014a) Scaling up pangolin protection in China. Frontiers in Ecology and the Environment 12: 97-98. doi: 10.1890/14.WB.001

Zhou Z-M, Zhou Y, Newman C, Macdonald DW (2014b) Synthetic ivory fails to stop illegal trade. Nature 507: 40. doi: 10.1038/507040a

Zhou Z-M, Johnson R, Newman C, Buesching CD, Macdonald DW, Zhou Y (2015a) Private possession drives IWT in China. Frontiers in Ecology and the Environment 13: 353-354. doi: 10.1890/15.WB.014

Zhou Z-M, Johnson R, Newman C, Buesching CD, Macdonald DW, Zhou Y (2015b) Tweak Chinese law to end ivory demand. Nature 518: 303. doi: 10.1038/518303c

Zhou Z-M, Newman C, Buesching CD, Macdonald DW, Meng X, Zhou Y (2015c) China: outdated listing puts species at risk. Nature 525: 187-187. doi: 10.1038/525187a

\section{Supplementary material I}

\section{CITES WCMC Trade database (2010-2014)}

Authors: Neil D'Cruze, David W. Macdonald

Data type: species data

Copyright notice: This dataset is made available under the Open Database License (http://opendatacommons.org/licenses/odbl/1.0/). The Open Database License $(\mathrm{ODbL})$ is a license agreement intended to allow users to freely share, modify, and use this Dataset while maintaining this same freedom for others, provided that the original source and author(s) are credited. 